\title{
Learner Views about Cooperative Learning in Social Learning Networks
}

\author{
Serkan Cankaya ${ }^{1}$ \& Eyup Yunkul ${ }^{1}$ \\ 1 Department of Computer Education and Instructional Technology, Necatibey Education Faculty, Balikesir \\ University, Balikesir, Turkey
}

Correspondence: Serkan Cankaya, Necatibey Education Faculty, Altieylul, Balikesir, Turkey. Tel: 90-266-241-2762. E-mail: serkancankaya@balikesir.edu.tr

\author{
Received: August 16, $2017 \quad$ Accepted: November 7, $2017 \quad$ Online Published: December 22, 2017 \\ doi:10.5539/ies.v11n1p52 URL: https://doi.org/10.5539/ies.v11n1p52
}

\begin{abstract}
The purpose of this study was to reveal the attitudes and views of university students about the use of Edmodo as a cooperative learning environment. In the research process, the students were divided into groups of 4 or 5 within the scope of a course given in the department of Computer Education and Instructional Technology. For each group, Edmodo small groups were formed, and the students used these Edmodo small groups to share and communicate with their group friends in relation to the group tasks assigned to them within the scope of the study. This process lasted one academic term. As the data collection tool, an online cooperative learning attitude scale and a semi-structured interview form were used. At the end of the academic term, 15 students were interviewed about their cooperative learning experiences within the scope of the course as well as about how they made use of Edmodo in the process. The results demonstrated that the students had positive attitudes towards online cooperative learning. The findings obtained via the qualitative data analysis were examined under the headings of "social networks used", "preferences of forming groups", "communication within group" and "views about the courses executed via Edmodo".
\end{abstract}

Keywords: Edmodo, social learning networks, online cooperative learning

\section{Introduction}

The rapid changes in students' expectations regarding effective learning and teaching (Durak \& Ataizi, 2016; Paechter, Maier, \& Macher, 2010) and the rapid spread of new technologies like social media (Arnold \& Paulus, 2010; Ebner, Lienhardt, Rohs, \& Meyer, 2010; Taylor, García-Peñalvo, Colomo-palacios, \& Lytras, 2012) have all brought about the need for renovations in education. In this respect, for the purposes of meeting these expectations and bringing renovations into teaching and learning processes, it is now necessary for teachers to train themselves regarding technology-enabled learning processes (Gan, Menkhoff, \& Smith, 2015; Paechter et al., 2010).

With the birth of Social Networking Sites (SNSs), it could be stated that online cooperative learning environments are among the renovations teachers should take into account (Cankaya, Durak, \& Yunkul, 2014). One should not ignore the idea that especially Facebook, with its millions of users, can be used as a potential teaching tool (Bosch, 2009; Kabilan, Ahmad, \& Abidin, 2010; Odabasi et al., 2012; Selwyn, 2009; Tonta, 2009). Although there are a number of studies demonstrating that SNSs can be successfully used as online learning environments (Al-Rahmi \& Othman, 2013; Ekici \& Kiyici, 2012; Forkosh-Baruch \& Hershkovitz, 2012; Grosseck, Bran, \& Tiru, 2011; Hung \& Yuen, 2010; R. Junco, Heiberger, \& Loken, 2011; Kabilan et al., 2010; Lawson, Kleinholz, \& Bodle, 2011; Mazer, Murphy, \& Simonds, 2007, 2009; Wodzicki, Schwämmlein, \& Moskaliuk, 2012), there are still other studies revealing that use of SNSs in education environments is likely to have negative effects on the learning process (Cohen, 2011; Reynol Junco, 2012; Karpinski \& Duberstein, 2009; Kirschner \& Karpinski, 2010; O’Brien, 2011; Rouis, Limayem, \& Salehi-sangari, 2011; Wang, Chen, \& Liang, 2011; Warner \& Esposito, 2009). Therefore, Social Learning Networks (SLNs), which removed the negative aspects of SNSs, appeared. SLNs function in a similar way to SNSs and basically serve as educational environments (Al-kathiri, 2015; Balasubramanian, Jaykumar, \& Fukey, 2014; Bicen, 2015; Trust, 2012). Today, use of this type of environments is increasing fast. Edmodo, the most popular SLN established in 2008, has reached more than 65 million users (Durak, Cankaya, \& Yunkul, 2014; Durak, Cankaya, Yünkül, \& Öztürk, 2017). Figure 1 shows a 
sample view of an Edmodo class.



Figure 1. A sample view of an Edmodo class

The present study on cooperative learning via Edmodo was based on the cooperative learning approach. This approach requires students to work in small groups for a common purpose (Wendt \& Rockinson-Szapkiw, 2014). Thanks to this, students are supposed to work together and learn by helping each other (Jacobsen, Eggen, \& Kauchak, 2002). According to the cooperative learning approach, students are expected to become individuals each of whom can think, produce and share their ideas (Tarim \& Akdeniz, 2003). In literature, there are many studies demonstrating that cooperative learning can be used successfully (Bye, Smith, \& Rallis, 2009; Ding \& Harskamp, 2011; Miller \& Benz, 2008; Parveen \& Batool, 2012; Yu, Tian, Vogel, \& Chi-Wai Kwok, 2010). The benefits of cooperative learning include motivation, feelings of success, mutual interdependence (Miller \& Benz, 2008), communication, level of satisfaction (Zhu \& Chang, 2012), cognitive growth, and socio-emotional growth (Parveen \& Batool, 2012; Wendt \& Rockinson-Szapkiw, 2014). Thanks to cooperation, students can build meaningful knowledge by sharing ideas and obtaining feedback from peers as mentioned in the constructivist learning theory (Dewiyanti, Brand-Gruwel, Jochems, \& Broers, 2007; Stump et al., 2011).

On the other hand, it is reported that cooperative learning in online environments are not as effective as face-to-face cooperative learning and that it is likely to cause communication problems between students. These communication problems could increase misunderstandings and result in lack of higher-order thinking (Hewitt, 2003; Rovai \& Jordan, 2004). In one experimental study carried out using the pretest-posttest design by Wendt \& Rockinson-Szapkiw (2014), the experimental group students participated in cooperative learning activities via Edmodo, while the control group students participated in face-to-face cooperative learning activities. The results revealed that the control group students were more successful and had fewer misconceptions. Although there are studies demonstrating that face-to-face cooperative learning environment is more effective than online cooperative learning environment, there are also some other studies reporting that online cooperative learning environments can be used as successfully as face-to-face cooperative learning environments and that online cooperative learning environments contribute to students' academic achievements (Durak, 2017; Erlandson, Nelson, \& Savenye, 2010; Johnson \& Johnson, 2004; Miller \& Benz, 2008). In this respect, SLNs, which are systems based on their members' sharings, naturally support cooperative learning and help students become social and active learners (Ajjan \& Hartshorne, 2008; Ozdamli \& Uzunboylu, 2008). In addition, the most important point that allows SLNs to be used successfully as an educational environment is that students achieve cooperative learning by sharing something interactively with one another (Inaba \& Mizoguchi, 2004; Mora-Soto, Sanchez-Segura, Medina-Dominguez, \& Amescua, 2009; Tinmaz, 2013). In one study conducted regarding use of SLNs in education, university students reported that their peers' views about their sharings contributed to their own learning (Wolf, Wolf, Frawley, Torres, \& Wolf, 2012).

In literature, there are studies in which Edmodo was used as a support to traditional courses which do not involve the use of the cooperative learning technique. However, as required by its nature, Edmodo somehow makes such courses cooperative. Besides, cooperative learning in Edmodo can be developed more with the help of the small-group feature of Edmodo and with the teacher's guidance of the students for cooperative learning. When 
the related literature is examined, it is seen that there is little research on the use of Edmodo especially as a cooperative learning environment (Brady, Holcomb, \& Smith, 2010; Bynum, 2011; Cankaya et al., 2014; Enriquez, 2014; Kongchan, 2008; Sanders, 2012). In this respect, it is important to reveal the related attitudes and views of students who use Edmodo for cooperative learning. From this perspective, the present study aimed to determine university students' attitudes and views about use of Edmodo as a cooperative learning environment.

\section{Method}

This part of the study, in which qualitative and quantitative data were collected together, presents information about the participants, the data collection tools and the analysis of the research data.

\subsection{Participants}

The participants of the study were $3^{\text {rd }}$ grade university students taking the course of Human-Computer Interaction in the department of Computer Education and Instructional Technology at Necatibey Education Faculty of Balikesir University in the academic year of 2013-2014. In the study, a total of 104 students filled in the Attitude Scale, and 15 students responded to the open-ended questions.

\subsection{Data Collection Tools}

In order to measure the participants' attitudes towards online cooperative learning, the Online Cooperative Learning Attitude Scale developed by Korkmaz (2012) was used. The scale included two factors: positive attitudes and negative attitudes.

For the purpose of examining the participants' cooperative learning experiences in Edmodo in more detail, a form made up of open-ended questions was prepared. While preparing the questions, the theoretical information obtained via review of the related literature and the theories underlying the present study were taken into account, and accordingly, the draft form was prepared. This draft form was examined by experts from the fields of educational technology, assessment and evaluation, and in line with their feedbacks, the form was finalized.

\subsection{Application Process}

In the study, within the scope of a course given in the department of Computer Education and Instructional Technology, the students were dived into project groups of 4 or 5. For each group, small groups were formed in Edmodo, and the students used their "Edmodo Small Groups" for sharing and communication with their group mates regarding the group tasks assigned to them within the scope of the course. This process continued for the whole academic term. The faculty member giving the course not only monitored the "Edmodo Small Groups" to see whether the groups functioned effectively or not but also gave them advice regarding the use of the system.

\subsection{Data Analysis}

The research data collected with the Attitude Scale were analyzed using the software of SPSS, and descriptive statistics, t-test and ANOVA were applied.

In relation to the qualitative data, each participant's responses were evaluated individually, and each researcher formed an interview coding key. The coding keys formed by the researchers were examined by a field expert in terms of reliability to evaluate the consistency between the coding keys. After ensuring consistency, the data were divided into themes based on the theoretical foundations of the study. In addition, direct quotations were given to reflect the students' views.

In qualitative studies, the process of data analysis includes three phases: description, analysis and interpretation (Yildirim \& Simsek, 2008). The description phase of data analysis focuses on determining what interviewees have said. In the analysis phase, relationship between the data and the themes obtained via the data are established. Lastly, the process ends with the interpretation of the findings within the research context.

\subsection{Validity and Reliability}

In the study, for validity purposes, the participants were informed about the fact that their views would be used only in an academic study and that their names would be kept confidential. In this way, the intention was to allow the participants to report their views sincerely. As for the reliability of the study, the findings obtained were presented without any related interpretation. In addition, the researchers of the study and a faculty member experienced in the field of qualitative research worked on the data together.

\section{Findings}

This part presents the findings obtained via the analyses. 


\subsection{Quantitative Findings}

In the study, a total of 104 students responded to the attitude scale regarding online cooperative learning applications. In this Likert-type scale, the items were assigned scores ranging from 1 (I completely disagree) and 5 (I completely agree). Table 1 presents the items of the scale and the mean scores regarding the students' responses.

Table 1. Students' responses to the attitude scale regarding online cooperative learning applications

\begin{tabular}{|c|c|c|c|}
\hline Themes & Items & $\bar{X}$ & $\mathrm{sd}$ \\
\hline \multirow{12}{*}{$\begin{array}{l}\text { Positive } \\
\text { Attitudes }\end{array}$} & $\begin{array}{l}\text { 1. I enjoy solving the problems regarding the group project together with my group mates in Online } \\
\text { Cooperative Learning Application (OCLA). }\end{array}$ & 3.87 & .966 \\
\hline & 2. Interacting with other group members in OCLA increases my motivation for learning. & 3.90 & .770 \\
\hline & 3. I enjoy having cooperative learning experiences together with my group mates in OCLA. & 3.85 & .932 \\
\hline & 4. Online group work increases our creativity. & 3.86 & .999 \\
\hline & 5. I believe the group will work on a document productively in OCLA. & 3.74 & .975 \\
\hline & 6. OCLA develops my social skills. & 3.61 & 1.074 \\
\hline & 7. I enjoy helping others in OCLA. & 4.07 & .741 \\
\hline & 8. OCLA is entertaining for me. & 3.33 & 1.009 \\
\hline & 9. OCLA allows me to feel psychologically better. & 3.33 & 1.028 \\
\hline & 10. More ideas are produced in OCLA. & 4.03 & .875 \\
\hline & 11. I think I get better results in OCLA as I work in group. & 3.66 & 1.076 \\
\hline & Mean & 3.75 & 7.820 \\
\hline \multirow{7}{*}{$\begin{array}{l}\text { Negative } \\
\text { Attitudes }\end{array}$} & 12. It makes me tired to try to teach something to my group mates in OCLA. & 2.71 & 1.081 \\
\hline & 13. I find OCLA nonsense. & 2.08 & 1.031 \\
\hline & 14. I cannot develop my own thoughts in OCLA. & 2.04 & .902 \\
\hline & 15. I don't like people being dependent on me in OCLA. & 3.13 & 1.180 \\
\hline & 16. I don't believe my interactions with my group mates in OCLA will contribute to me. & 2.63 & 1.255 \\
\hline & 17. OCLA is not for me. & 2.30 & 1.051 \\
\hline & Mean & 2.48 & 4.360 \\
\hline
\end{tabular}

When the mean scores regarding the students' responses to the positive attitude items in Table 1 were examined, it was seen that the students generally obtained a mean score of around 4. In other words, the students' responses could be said to be at the level of "I Agree". However, the students' responses especially to two of the items were found to be closer to the level of 3 ("I am Neutral"). These two items were "OCLA is entertaining for me" and "OCLA allows me to feel psychologically better". Although the students thought OCLA contributed to their learning, it could be concluded that they did not regard OCLA as an environment of entertainment. When the students' responses to the negative attitude items were examined, it was seen that five items were lower than 3 and that most of the students did not agreed on these items. On the other hand, in one of the items considered to be a negative attitude, the students had a mean score higher than 3. This item was "I don't like people being dependent on me in OCLA". One of the problems likely to be experienced in group works was that the group members did not work equally. Some of the group members worked harder, while some of them worked less. Therefore, the group members working hard might have been uncomfortable with this situation. The course instructor should be able to evaluate group members' works well. In fact, in a course in which the cooperative learning technique is used, the course instructor could easily evaluate group members' works thanks to their sharings via the application of "Edmodo Small Groups". However, it was seen that the students had hesitations regarding this.

The mean scores of the participants regarding positive and negative themes of the attitude scale were compared with respect to the variables of gender, type of high school and GPA. In order to do such comparisons, mean scores must demonstrate a normal distribution. The participants' mean scores for the positive attitudes in the scale ranged from 1.36 to $5.00(\mathrm{M}=3.75, \mathrm{SD}=0.71)$ and demonstrated a normal distribution with skewness of $0.57(\mathrm{SE}=0.24)$ and kurtosis of $0.41(\mathrm{SE}=0.47)$. As for the participants' mean scores for the negative attitudes in the scale, they ranged from 1.00 to $5.00(\mathrm{M}=2.48, \mathrm{SD}=0.72)$ and demonstrated a normal distribution with skewness of $0.56(\mathrm{SE}=0.24)$ and kurtosis of $0.80(\mathrm{SE}=0.47)$. In order to reveal whether the participants' mean scores regarding the positive and negative attitudes in the scale differed significantly with respect to the variable of gender, independent samples t-test was applied, and the results can be seen in Table 2. 
Table 2. t-Test results regarding the positive and negative attitudes with respect to gender

\begin{tabular}{lccccc}
\hline & \multicolumn{2}{c}{ Female } & \multicolumn{3}{c}{ Male } \\
\hline & M & SD & M & SD & $\mathrm{p}^{*}$ \\
Positive Attitudes & 3.78 & 0.62 & 3.72 & 0.80 & 0.66 \\
Negative Attitudes & 2.42 & 0.69 & 2.54 & 0.76 & 0.41 \\
\hline
\end{tabular}

$* \mathrm{p}<0.05, \mathrm{~N}=104$.

As can be seen in Table 2, there was no significant difference between the male and female students' attitude scores. For the purpose of determining the influence of the type of high school the participants had graduated from on their attitude scale scores, independent samples t-test was used. Table 3 demonstrates the results obtained.

Table 3. t-Test results regarding the positive and negative attitudes with respect to the type of high school the participants had graduated from

\begin{tabular}{lccccccc}
\hline \multicolumn{5}{c}{ Vocational High School } & \multicolumn{3}{c}{ Other High Schools } \\
\hline & $\mathrm{M}$ & $\mathrm{SD}$ & $\mathrm{M}$ & $\mathrm{SD}$ & $\mathrm{p}^{*}$ \\
& Positive Attitudes & 3.80 & 0.64 & 3.59 & 0.86 & 0.18 \\
Negative Attitudes & 2.44 & 0.69 & 2.57 & 0.80 & 0.35 \\
\hline
\end{tabular}

$* \mathrm{p}<0.05, \mathrm{~N}=104$.

According to Table 3, no significant difference was found between the attitude mean scores of the students graduating from a vocational high school and of the students graduating from other high schools. In the questionnaire applied in the study, the students were also asked about their GPA, and their responses were transformed into a categorical variable. The categories were as follows: less than 1.5, between 1.5-2, between 2-2.5, between 2.5 and 3 and higher than 3 . In order to reveal whether there was a significant difference between the attitude scores with respect to the categories of the variable of GPA, ANOVA was applied. The results obtained can be seen in Table 4.

Table 4. One way ANOVA results regarding the positive and negative attitudes with respect to GPA scores

\begin{tabular}{ccccccc}
\hline & Source of Variance & Sum of Squares & df & Mean Square & F & p \\
\cline { 2 - 7 } Positive Attitudes & Between Groups & 1,389 & 4 &, 347 &, 679 &, 608 \\
& Within Groups & 50,664 & 99 &, 512 & & \\
& Total & 52,053 & 103 & & & \\
\hline \multirow{2}{*}{ Negative Attitudes } & Between Groups & 2,170 & 4 &, 543 & 1,037 &, 392 \\
& Within Groups & 51,810 & 99 &, 523 & & \\
& Total & 53,980 & 103 & & & \\
\hline
\end{tabular}

$* \mathrm{p}<0.05, \mathrm{~N}=104$.

When Table 4 is examined, it is seen that there was no significant difference between the attitude scores with respect to the categories of GPA. In other words, no significant difference was found between the attitudes of the students with different levels of academic achievement.

\subsection{Qualitative Findings}

The data obtained via the analysis of the qualitative findings were coded, and the themes were formed. The findings obtained based on the individual interviews were grouped under the following headings: social networks used, preferences of forming groups, communication within group, views about the courses executed via Edmodo.

\subsubsection{Social Networks Used}

The participants were asked to state which social networks they used. All the participants reported that they used WhatsApp, and 14 of them said they used Facebook. Besides these two social networks, Twitter was used by 8 participants; Instagram by 6 ; and LinkedIn was used by 3 of the participants. 


\subsubsection{Preferences of Forming Groups}

The participants were also directed to the question of "What are your preferences of forming groups". In addition, more in-depth information was obtained asking the questions of a-) Why are you with these friends? and b-) How did you form the group? The views of 15 participants responding to the question were analyzed. The frequency distribution of the items under the theme of favorable characteristics of group friends can be seen in Table 5 .

Table 5. Preferences of forming groups

\begin{tabular}{ll}
\hline Favorable characteristics of group friends & $\mathrm{f}$ \\
\hline Having the feeling of responsibility & 12 \\
Being a close friend & 11 \\
Past experiences & 9 \\
Adaptation to team work & 9 \\
Showing understanding & 8 \\
Common goals & 5 \\
Being honest and frank & 5 \\
Being respectful & 4 \\
Having the necessary knowledge and skills & 4 \\
Individuals with different viewpoints & 3 \\
\hline
\end{tabular}

Table 5 demonstrates the participants' preferences of forming groups. Among all the characteristics, the one favored most for group friends by the participants was "Having the feeling of responsibility". In addition, most of the participants stated that "Being a close friend" was another characteristic they considered while forming a group. These two characteristics were followed by "Past experiences", "Adaptation to team work" and "Showing understanding". The other responses included "Common goals", "Being honest and frank", "Being respectful", "Having the necessary knowledge and skills" and "Individuals with different viewpoints". For example, in relation to this, one of the participants said "We wanted friends who complement one another. We formed a group including individuals who respect to each other and who can take the responsibility".

\subsubsection{Communication within Group}

The participants were asked the question of "How was your communication within your group throughout the academic term?". In addition, other questions directed to obtain more in-depth information included "a) Where did you meet? b) Which type of communication did you prefer (Individual/Group)? Why? c) Which tool/media (did you use for communication (Edmodo, Facebook, skype, mobile phone, and so on)? d) How did you inform each other about the changes experienced in the process?". The views of 15 participants responding to the question were analyzed. Table 6 demonstrates the frequency distribution regarding the items under the themes of place of meeting, communication preferences, media used in communication, influence of effective communication on group success and communication problems within group.

Table 6. Communication within group

\begin{tabular}{ll}
\hline Place of meeting & $\mathrm{f}$ \\
$\quad$ Virtual place (Facebook, WhatsApp) & 15 \\
Real place (school, home, café and so on) & 14 \\
Communication preferences & 15 \\
$\quad$ Group & 4 \\
Individual & \\
Media used in communication & 15 \\
Edmodo & 14 \\
Facebook group & 4 \\
WhatsApp group & \\
Influence of effective communication on group success & \\
Active participation & 9 \\
Increasing motivation & 6 \\
Completing the project in time & 5 \\
\hline
\end{tabular}


Communication problems within group

Irresponsible participants 3

Personal problems (family-related, financial) 2

Under the theme of communication within group, the sub-themes included place of meeting, communication preferences, media used in communication, influence of effective communication on group success, and communication problems within group. The participants maintained their communication within group both via virtual environments and in real places. The meetings in virtual environments were held via such applications as Facebook and WhatsApp, while face-to-face meetings were held in places like school, home and café. When the participants were asked about their communication preferences, all of them stated that they established communication via the group, and four of them reported that they met in pairs. When the participants were asked about the environments they used for communication, all of them stated that they used Edmodo which was also used as a medium to execute the course. In addition, almost all the participants reported that they used Facebook, and some of them said used WhatsApp besides Facebook. For instance, one of the students said "We met in a café. We made our decisions there. Then, everyone worked individually. We used Edmodo to communicate with each other."

When the participants were asked about the contribution of communication to the success of their groups, "active participation" ranked first. This response was followed by "increasing motivation" and "completing the project in time". For example, one of the students said "Our constant communication resulted in our success in the phases of the project and helped us progress in our project in line with our teacher's directions" In addition, the students were asked about communication problems within group. This question was answered by few of the students, and the related responses included the problems resulting from the irresponsible participants in the groups and some other personal problems.

\subsubsection{Views about the Course Executed via Edmodo}

The participants responded to the question of "Could you please evaluate the course in general?". The views of the students responding to the question were analyzed. Table 7 presents the frequency distribution for the items under the theme of Views about the Course Executed via Edmodo.

Table 7. Views about the course executed via Edmodo

\begin{tabular}{ll}
\hline Views about the Course Executed via Edmodo & $\mathrm{f}$ \\
\hline The course was executed based on discussions and active participation & 12 \\
It was an interesting course different from traditional methods & 10 \\
It contributed to learning & 9 \\
It constantly helped maintain our motivation & 7 \\
The activities took a lot of time & 4 \\
\hline
\end{tabular}

The participants reported that they carried out discussion-based applications with the help of this course supported with Edmodo and that they actively participated in the course. This response was followed by "it was an interesting course different from traditional methods". The other responses were related to the students' motivation and the contribution of the course to their learning. On the other hand, some of the participants stated that it took a considerable amount of time to carry out activities via such discussion-based applications.

\section{Conclusion, Discussion and Suggestions}

The study was conducted within the scope of a course, and the students taking the course were divided into project group of 4 or 5. The course was supported with Edmodo. The students were expected to work in cooperation, and the process was executed by the instructor. The findings obtained via the scale applied to the students at the end of the course revealed that most of the students had positive attitudes towards online cooperative learning applications.

The results obtained via the individual interviews held with the students who experienced cooperative learning were evaluated with respect to the social networks used, preferences of forming groups, communication within group, and overall views about the course executed via Edmodo. Based on the results, it could be stated that the students made active use of information and communication technologies because almost all the students were users of WhatsApp and Facebook. This situation could be said to help the students adapt themselves easily to the 
online cooperative learning environment of Edmodo, which has a similar structure to Facebook.

In related literature, there are three different approaches to forming groups regarding cooperative learning: random selection, self-selection and instructor-selection. These three methods have specific advantages and disadvantages (Sadeghi \& Kardan, 2016). In the present study, the self-selection approach was adopted, and the process of forming groups was conducted by the students. The students' preferences of forming groups were examined in-depth, and their responses in relation to forming groups revealed that they mostly preferred their close friends as well as other individuals who had the feeling of responsibility. This finding is consistent with the results of other studies in related literature reporting that learners prefer groups with individuals who take the responsibility (Duque, Gomez-Perez, Nieto-Reyes, \& Bravo, 2015). In addition, it is reported in relation to group members' forming groups that they favor individuals who will decrease their own workloads (Worchel, Rothgerber, \& Day, 2009). Preferring individuals with the feeling of responsibility will naturally help decrease students' workloads in their group works. Also, in one study, it was found that friendship relations play an important role in forming a group if students form their groups on their own (Moreno, Ovalle, \& Vicari, 2012). Lastly, past experiences and adaptation to team work were also among the characteristics considered to be important by the students.

Under the heading of communication within group, the students were asked about the platforms they used during the activities and about their communication preferences. It was found that the students met their communication needs almost equally via virtual and real environments. In addition, it was seen that the students favored group communication more when compared to individual communication. When they were asked about the media they used for communication, it was found that Edmodo, the platform which was used to execute the course, was used by all the students as a means for communication. As the course was supported with Edmodo, it could be stated that the students naturally used Edmodo for communication purposes. In addition, the instructor has the opportunity to monitor students' correspondences via Edmodo. Also, Edmodo does not allow individual communication between students. Besides Edmodo, almost all the students reported that they established communication via Facebook in relation to their group works. This result might have been due to the fact that Facebook is a quite a commonly-used social network; that it was easy for the students to use this social network; that they sometimes needed to establish personal communication; and that they did not want the instructor to see some of their correspondences. In the study, the students were asked about the effects of their communication activities on their group success, and their responses revealed that communication activities could increase their active participation and motivation. In addition to this, the students also reported that communication activities could help complete the project or the work in time. Lastly, under this heading, the students who experienced cooperative learning were asked about the communication problems they faced within group. The students stated that they experienced problems due to their irresponsible friends in their groups. As can be remembered, this result was also found to be the most important result under the theme of preferences of forming groups.

When the students who experienced cooperative learning were asked about Edmodo, which was used to execute the course, among the most frequent response was active participation achieved thanks to the discussion-based structure of the course. This result could be said to be one of possible consequences of cooperative learning. This response was followed by the view that such a course was more interesting than other courses taught with traditional methods. The fact that the students found the course interesting could be said to increase their motivation for the course. One other response was that such a course could help them learn the course subjects better. This view is supported by the result reported in related literature that courses involving cooperative learning contribute to learning (Al-Rahmi \& Othman, 2013; Biasutti, 2011; Ekici \& Kiyici, 2012; Forkosh-Baruch \& Hershkovitz, 2012; Grosseck et al., 2011; Hung \& Yuen, 2010; R. Junco et al., 2011; Kabilan et al., 2010; Lawson et al., 2011; Mazer et al., 2007, 2009; Wodzicki et al., 2012). Despite all these positive views, there were some other students with negative views who reported that it took quite a lot of time for them to carry out the activities involving cooperative learning. However, this result might have been due to the problems experienced by the students who had difficulty adapting themselves to the cooperative learning activities.

\section{References}

Ajjan, H., \& Hartshorne, R. (2008). Investigating faculty decisions to adopt Web 2.0 technologies: Theory and empirical tests. The Internet and Higher Education, 11(2), 71-80. http://doi.org/10.1016/j.iheduc.2008.05.002

Al-kathiri, F. (2015). Beyond the classroom walls: Edmodo in Saudi secondary school EFL instruction, attitudes and challenges. English Language Teaching, 8(1), 189-204. http://doi.org/10.5539/elt.v8n1p189

Al-Rahmi, W. M., \& Othman, M. S. (2013). The impact of social media use on academic performance among 
university students: A pilot study. Journal of Information Systems Research and Innovation, 4(2), 1-10.

Arnold, N., \& Paulus, T. (2010). Using a social networking site for experiential learning: Appropriating, lurking, modeling and community building. The Internet and Higher Education, 13(4), 188-196. http://doi.org/10.1016/j.iheduc.2010.04.002

Balasubramanian, K., Jaykumar, V., \& Fukey, L. N. (2014). A study on student preference towards the use of Edmodo as a learning platform to create responsible learning environment. Procedia - Social and Behavioral Sciences, 144, 416-422. http://doi.org/10.1016/j.sbspro.2014.07.311

Biasutti, M. (2011). The student experience of a collaborative e-learning university module. Computers \& Education, 57(3), 1865-1875. http://doi.org/10.1016/j.compedu.2011.04.006

Bicen, H. (2015). The role of social learning networks in mobile assisted language learning: Edmodo as a case study. Journal of Universal Computer Science, 21(10), 1297-1306.

Bosch, T. E. (2009). Using online social networking for teaching and learning: Facebook use at the University of Cape Town. South African Journal for Communication Theory and Research, 35(2), 185-200.

Brady, K. P., Holcomb, L. B., \& Smith, B. V. (2010). The use of alternative social networking sites in higher educational settings: A case study of the e-learning benefits of ning in education. Journal of Interactive Online Learning, 9(2), 151-170.

Bye, L., Smith, S., \& Rallis, H. M. (2009). Reflection using an online discussion forum: Impact on student learning and satisfaction. Social Work Education, 28(8), 841-855. http://doi.org/10.1080/02615470802641322

Bynum, S. L. (2011). Utilizing social media to increase student engagement: A study of Kern County public schools. (Unpublished mater's thesis). California State University Department of Public Policy and Administration, Bakersfield.

Cankaya, S., Durak, G., \& Yunkul, E. (2014). Using educational social networking sites in higher education: edmodo through the lenses of undergraduate students. European Journal of Education Technology, 1(1), 3-23.

Cohen, A. (2011). Higher education students' perspectives of the relevance of the online social networking site Facebook to education. (Unpublished doctoral dissertation). Walden University College of Social and Behavioral Sciences.

Dewiyanti, S., Brand-Gruwel, S., Jochems, W., \& Broers, N. J. (2007). Students' experiences with collaborative learning in asynchronous Computer-Supported Collaborative Learning environments. Computers in Human Behavior, 23(1), 496-514. http://doi.org/10.1016/j.chb.2004.10.021

Ding, N., \& Harskamp, E. G. (2011). Collaboration and peer tutoring in chemistry laboratory education. International Journal of Science Education, 33(6), 839-863. http://doi.org/10.1080/09500693.2010.498842

Duque, R., Gomez-Perez, D., Nieto-Reyes, A., \& Bravo, C. (2015). Analyzing collaboration and interaction in learning environments to form learner groups. Computers in Human Behavior, 47, $42-49$. http://doi.org/10.1016/j.chb.2014.07.012

Durak, G. (2017). Using Social Learning Networks ( SLNs ) in higher education: Edmodo through the lenses of academics. International Review of Research in Open and Distributed Learning, 18(1), 84-109. http://doi.org/10.19173/irrodl.v18i1.2623

Durak, G., \& Ataizi, M. (2016). Learner views about a distance education course. Contemporary Educational Technology, 7(1), 85-105. Retrieved from http://cedtech.net/articles/71/715.pdf

Durak, G., Cankaya, S., \& Yunkul, E. (2014). Using educational social networking sites in education: Edmodo. Dumlupınar University Journal of Social Sciences, 41, 309-316. http://doi.org/10.1007/s13398-014-0173-7.2

Durak, G., Cankaya, S., Yünkül, E., \& Öztürk, G. (2017). The effects of a social learning network on students' performances and attitudes. European Journal of Education Studies, 3(3), 312-333. http://doi.org/10.5281/zenodo.292951

Ebner, M., Lienhardt, C., Rohs, M., \& Meyer, I. (2010). Microblogs in higher education - A chance to facilitate informal and process-oriented learning? Computers and Education, 55(1), 92-100. http://doi.org/10.1016/j.compedu.2009.12.006 
Ekici, M., \& Kiyici, M. (2012). Sosyal aglarin egitim baglaminda kullanimi. Usak Universitesi Sosyal Bilimler Dergisi, 5(2), 156-167.

Enriquez, M. A. S. (2014). Students' perceptions on the effectiveness of the use of edmodo as a supplementary tool for learning. In DLSU Research Congress (pp. 1-6). De La Salle University, Manila, Philippines.

Erlandson, B. E., Nelson, B. C., \& Savenye, W. C. (2010). Collaboration modality, cognitive load, and science inquiry learning in virtual inquiry environments. Educational Technology Research and Development, 58(6), 693-710. http://doi.org/10.1007/s11423-010-9152-7

Forkosh-Baruch, A., \& Hershkovitz, A. (2012). A case study of Israeli higher-education institutes sharing scholarly information with the community via social networks. The Internet and Higher Education, 15(1), 58-68. http://doi.org/10.1016/j.iheduc.2011.08.003

Gan, B., Menkhoff, T., \& Smith, R. (2015). Enhancing students' learning process through interactive digital media: New opportunities for collaborative learning. Computers in Human Behavior, 51(0), 652-663. http://doi.org/10.1016/j.chb.2014.12.048

Grosseck, G., Bran, R., \& Tiru, L. (2011). Dear teacher, what should I write on my wall? A case study on academic uses of Facebook. Procedia - Social and Behavioral Sciences, 15(2011), 1425-1430. http://doi.org/10.1016/j.sbspro.2011.03.306

Hung, H.-T., \& Yuen, S. C.-Y. (2010). Educational use of social networking technology in higher education. Teaching in Higher Education, 15(6), 703-714. http://doi.org/10.1080/13562517.2010.507307

Inaba, A., \& Mizoguchi, R. (2004). Learners role and predictible benefits in collaborative learning. In Proceedings of International Conference on Intellegent Tutoring Systems (pp. 285-294). Alagoas.

Jacobsen, D. A., Eggen, P., \& Kauchak, D. (2002). Methods for teaching (6. ed). Upper Saddle River, NJ: Merrill-Prentice Hall.

Johnson, D., \& Johnson, R. (2004). Cooperation and the use of technology. In D. Jonassen (Ed.), Handbook of research on educational communications and technology (2nd ed., pp. 785-812). Erlbaum: Mahwah.

Junco, R. (2012). The relationship between frequency of Facebook use, participation in Facebook activities, and $\begin{array}{lllll}\text { student engagement. Computers \& } & \text { Education, } & \text { 58(1), }\end{array}$ http://doi.org/10.1016/j.compedu.2011.08.004

Junco, R., Heiberger, G., \& Loken, E. (2011). The effect of Twitter on college student engagement and grades. Journal of Computer Assisted Learning, 27(2), 119-132. http://doi.org/10.1111/j.1365-2729.2010.00387.x

Kabilan, M. K., Ahmad, N., \& Abidin, M. J. Z. (2010). Facebook: An online environment for learning of English in institutions of higher education? The Internet and Higher Education, 13(4), 179-187. http://doi.org/10.1016/j.iheduc.2010.07.003

Karpinski, A. C., \& Duberstein, A. (2009). A description of facebook use and academic performance among undergraduate and graduate students. In American Educational Research Association Annual Meeting. San Diego, California.

Kirschner, P. A., \& Karpinski, A. . (2010). Facebook and academic performance. Computers in Human Behavior, $26,1237-1245$.

Kongchan, C. (2008). How a non-digital-native teacher makes use of edmodo. In 5th Intenational Conference ICT for Language Learning. Florence.

Korkmaz, Ö. (2012). A validity and reliability study of the Online Cooperative Learning Attitude Scale (OCLAS). Computers \& Education, 59(4), 1162-1169. http://doi.org/10.1016/j.compedu.2012.05.021

Lawson, T. J., Kleinholz, S. A., \& Bodle, J. H. (2011). Using Facebook to connect alumni, current students, and faculty: A how-to guide. Teaching of Psychology, 38(4), 265-268. http://doi.org/10.1177/0098628311421327

Mazer, J. P., Murphy, R. E., \& Simonds, C. J. (2007). I'll see you on "Facebook": The effects of computer-mediated teacher self-disclosure on student motivation, affective learning, and classroom climate. Communication Education, 56(1), 1-17. http://doi.org/10.1080/03634520601009710

Mazer, J. P., Murphy, R. E., \& Simonds, C. J. (2009). The effects of teacher self-disclosure via Facebook on teacher credibility. Learning, Media and Technology, 34(2), 175-183. http://doi.org/10.1080/17439880902923655 
Miller, R. L., \& Benz, J. J. (2008). Techniques for encouraging peer collaboration: Online threaded discussion or fishbowl interaction. Journal of Instructional Psychology, 35(1), 87-93.

Mora-Soto, A., Sanchez-Segura, M.-I., Medina-Dominguez, F., \& Amescua, A. (2009). Collaborative learning experiences using social networks. In Proceedings of 1st International Conference on Education and New Learning Technologies (pp. 4260-4270). Barcelona ,Spain. Retrieved from http://library.iated.org/view/MORASOTO2009COL

Moreno, J., Ovalle, D. A., \& Vicari, R. M. (2012). A genetic algorithm approach for group formation in collaborative learning considering multiple student characteristics. Computers and Education, 58(1), 560-569. http://doi.org/10.1016/j.compedu.2011.09.011

O'Brien, S. J. (2011). Facebook and other Internet use and the academic performance of college students. (Unpublished doctoral dissertation). The Temple University Graduate School.

Odabasi, H. F., Misirli, O., Gunuc, S., Timar, Z. S., Ersoy, M., Som, S., ... Erol, O. (2012). Egitim icin yeni bir ortam: Twitter. Anadolu Journal of Educational Sciences International, 2(1), 89-103.

Ozdamli, F., \& Uzunboylu, H. (2008). Ogretmen adaylarinin teknoloji destekli isbirlikli ogrenme ortamina yonelik. Cypriot Journal Of Educational Sciences, 5, 28-36.

Paechter, M., Maier, B., \& Macher, D. (2010). Students' expectations of, and experiences in e-learning: Their relation to learning achievements and course satisfaction. Computers and Education, 54(1), 222-229. http://doi.org/10.1016/j.compedu.2009.08.005

Parveen, Q., \& Batool, S. (2012). Effect of cooperative learning on achievement of students in general science at secondary level. International Education Studies, 5(2), 154-158. http://doi.org/10.5539/ies.v5n2p154

Rouis, S., Limayem, M., \& Salehi-sangari, E. (2011). Impact of facebook usage on students' academic achievement: roles of self-regulation and trust. Electronic Journal of Research in Educational Psychology, 9(3), 961-994.

Sadeghi, H., \& Kardan, A. A. (2016). Toward effective group formation in computer- supported collaborative learning. Interactive Learning Environments, 24(3), 382-395. http://doi.org/10.1080/10494820.2013.851090

Sanders, K. S. (2012). An examination of the academic networking site Edmodo on student engagement and responsible learning. (Unpublished doctoral dissertation). University of South Carolina College of Education.

Selwyn, N. (2009). Faceworking: exploring students' education-related use of Facebook. Learning, Media and Technology, 34(2), 157-174. http://doi.org/10.1080/17439880902923622

Stump, G. S., Hilpert, J. C., Husman, J., Chung, W., Kim, W., \& Education, E. (2011). Collaborative learning in engineering students: gender and achievement. Journal of Engineering Education, 100(3), 475-497. http://doi.org/10.1002/j.2168-9830.2011.tb00023.x

Tarim, K., \& Akdeniz, F. (2003). IIlkogretim matematik derslerinde kubasik ogrenme yonteminin kulanilmasi. Hacettepe Universitesi Egitim Fakultesi Dergisi, 24, 215-223.

Taylor, P., García-Peñalvo, F. J., Colomo-palacios, R., \& Lytras, M. D. (2012). Informal learning in work environments: training with the Social Web in the workplace. Behaviour \& Information Technology, 31(8), 753-755. http://doi.org/10.1080/0144929X.2012.661548

Tinmaz, H. (2013). Sosyal ag web siteleri ve sosyal aglarin egitimde kullanimi. In K. Cagiltay \& Y. Goktas (Eds.), Ogretim Teknolojilerinin Temelleri: Teoriler, Arastirmalar, Egilimler (pp. 615-630). Ankara: Pegem Akademi.

Tonta, Y. (2009). Dijital yerliler, sosyal aglar ve kutuphanelerin gelecegi. Turk Kutuphaneciligi, 23(4), 742-768.

Trust, T. (2012). Professional learning networks designed for teacher learning. Journal of Digital Learning in Teacher Education, 28(4), 133-138. http://doi.org/10.1080/21532974.2012.10784693

Wang, Q., Chen, W., \& Liang, Y. (2011). The effects of social media on college students. Johnson \& Wales University ScholarsArchive@JWU MBA Student Scholarship. Retrieved from http://scholarsarchive.jwu.edu/mba_student/5/

Warner, B., \& Esposito, J. (2009). What's not in the syllabus: Faculty transformation, role modeling and role conflict in immersion service-learning courses. International Journal of Teaching and Learning in Higher Education, 20(3), 510-517. 
Wendt, J. L., \& Rockinson-Szapkiw, A. (2014). The effect of online collaboration on middle school student science misconceptions as an aspect of science literacy. Journal of Research in Science Teaching, 51(9), 1103-1118. http://doi.org/10.1002/tea.21169

Wodzicki, K., Schwämmlein, E., \& Moskaliuk, J. (2012). “Actually, I wanted to learn”: Study-related knowledge exchange on social networking sites. The Internet and Higher Education, 15(1), 9-14. http://doi.org/10.1016/j.iheduc.2011.05.008

Wolf, M. M., Wolf, M., Frawley, T., Torres, A., \& Wolf, S. (2012). Using social media to enhance learning through collaboration in higher education: a case study. In Agricultural Economics Association 2012 Annual Meeting. Seattle, Washington.

Worchel, S., Rothgerber, H., \& Day, E. A. (2009). Social loafing and group development: When “'I”" comes last. Current Research In Social Psychology, 17(5), 461-482.

Yildirim, A., \& Simsek, H. (2008). Sosyal Bilimlerde Nitel Arastirma Yontemleri (6. baski). Ankara: Seckin Yayinevi.

Yu, A. Y., Tian, S. W., Vogel, D., \& Chi-Wai Kwok, R. (2010). Can learning be virtually boosted? An investigation of online social networking impacts. Computers \& Education, 55(4), 1494-1503. http://doi.org/10.1016/j.compedu.2010.06.015

Zhu, C., \& Chang, Z. (2012). Student satisfaction, performance, and knowledge construction in online collaborative learning. Journal of Educational Technology \& Society, 15(1), 127-136.

\section{Copyrights}

Copyright for this article is retained by the author(s), with first publication rights granted to the journal.

This is an open-access article distributed under the terms and conditions of the Creative Commons Attribution license (http://creativecommons.org/licenses/by/4.0/). 